\title{
Designing of a New Type Air-Water Cooled Photovoltaic Collector
}

\author{
Erhan Arslan, Azim Doğuş Tuncer, Meltem Koşan, Mustafa Aktaş, Ekin Can Dolgun
}

\begin{abstract}
The importance of photovoltaic-thermal (PV / T) collector systems in renewable energy technologies is increasing for combined hybrid electrical heat applications. The efficiency of photovoltaic (PV) systems varies between $5-20 \%$. On average, $15 \%$ of the solar radiation coming to the PV panel surface is converted to electrical energy and the remainder is lost. In this study, a PV/T collector was designed using two different fluids simultaneously and its efficiency was calculated numerically. PV/T collector systems are specifically designed for agricultural production and their advantages are discussed. In this study, numerical calculations of PV/T collector with a different design have been made. The results were compared with reference to another experimental study. Two different working fluids (air and water) were used in the calculations. The system where air is used as working fluid is called Mode 1 and the system where water is used is called Mode 2. It is aimed to achieve high heat transfer by using water pipes, air ducts and fins placed under PV panels. In this way, it is aimed to produce a more stable hot air and water. In addition, in order to investigate the effect of flow on the yield, different flow rates were calculated. As a result of the theoretical analyses and calculations made in consideration of literature, the total efficiencies of air flow mode (Mode 1) were calculated as $43.2 \%$, $46,2 \%$ and $48.7 \%$ at $0.0067 \mathrm{~kg} / \mathrm{s}, 0.0072 \mathrm{~kg} / \mathrm{s}$ and $0.0077 \mathrm{~kg} / \mathrm{s}$ mass flow rates, respectively. For water flow mode (Mode 2), these values computed as $52.81 \%, 53.83 \%$ and $55.04 \%$ at $0.023 \mathrm{~kg} / \mathrm{s}, 0.036 \mathrm{~kg} / \mathrm{s}$ and $0.054 \mathrm{~kg} / \mathrm{s}$ mass flow rates, respectively. It was found that PV / T collector efficiency increased with increasing end flow. Designed collector system is preferable in terms of effective use of energy and it can be easily applicable in processes such as hot air-water preparation, drying and greenhouse heating.
\end{abstract}

Keywords: air-water heating; hybrid renewable energy systems; photovoltaic-thermal collector; solar energy

\section{INTRODUCTION}

Energy demand across the world is increasing day by day, but only fossil fuel based energy systems are not enough to meet this demand. Therefore, renewable energy technologies are one of the most important areas of research of our time. The utilization of renewable energy sources is also possible with the use of hybrid systems. Solar energy is at the forefront of renewable and sustainable energy research and is used globally for the production of electrical and thermal energy [1-2]. The basis of environmental and economical sustainability depends on the use of renewable energy sources. Hybrid technologies allow to use renewable energy sources and technologies effectively.

Photovoltaic systems can convert only $15-20 \%$ of the solar energy and the rest being turned into heat. It is possible to effectively use the heat which cannot transform into electrical energy with photovoltaic-thermal collectors (PV/T). Also, PV/T collector system allows to decrease the temperature of the photovoltaic panel. Thus, efficiency of the photovoltaic (PV) panel would be increased.

Concentrating $\mathrm{PV} / \mathrm{T}(\mathrm{CPV} / \mathrm{T})$ collector collects solar radiation and reflects to a focal spot where the PV panel is located. The benefit of using concentrating PV/T collectors is that the use of reflector material, which is inexpensive compared with PV modules, makes for the use of less PV modules by comparison with flat plate PV/T collectors. By doing so, costly PV modules are switched with economically viable reflector apparatus [3].

Fossil fuels which are primary energy sources are commonly used for heating applications, which is necessary for the food and agricultural production such as drying, preheating. The utilization of $\mathrm{PV} / \mathrm{T}$ technologies in these applications is very important in terms of benefits from the sun. In this manner, energy costs and carbon emissions will be reduced as the usage of fossil fuels declines. The use of $\mathrm{PV} / \mathrm{T}$ technology eliminates the need for an additional system for electrical energy. In this way, energy costs can be reduced.

Kalogirou and Tripanagnostopoulos [4] carried out the cost analysis of electricity production from $\mathrm{PV} / \mathrm{T}$ for domestic hot water supply. As a result, they found that the system could be applied economically. In research conducted by Ceylan et al., [5] the PV module was cooled by water flowing through the spiral pipes connected to the back of the module with temperature control. Designed to keep the temperature of the photovoltaic module at $45{ }^{\circ} \mathrm{C}$, the noncooled and cooled efficiency of the electrical efficiency of the whole system was tested at $10 \%$ and $13 \%$. Ceylan and Gürel [6] experimentally studied the cooling of the PV module in their study. The PV efficiency was calculated as $17 \%$ at $45{ }^{\circ} \mathrm{C}$ and the exergy efficiency at $55^{\circ} \mathrm{C}$ at $21 \%$. In a study performed by Zondag [7], a glazed PV/T, an unglazed $\mathrm{PV} / \mathrm{T}$ and a conventional PV panel were compared. Mean electrical efficiencies were calculated as 7.6\%,7.2\% and 6.6, respectively. Specifications and efficiencies of previous works of PV/T systems are given in Tab. 1.

Solar air collectors are inexpensive and easily applicable systems which produces thermal energy from solar radiation with a small amount of electrical energy consumption. Aktaş et al. [8] performed energy-exergy analysis of a multipass solar air collector. According to the results, average thermal efficiency of the collector reaches up to $72 \%$. In a study conducted by Şevik et al. [9] Double pass solar air collector was used in a drying application of mint and apple samples.

Integration of PV panels and solar collector systems allows to increase both electrical and thermal efficiency values with $\mathrm{PV} / \mathrm{T}$ technology. In this study, a novel PV/T collector system was designed. Air and water were chosen as the working fluids for Mode 1 and Mode 2, respectively. The collector has been designed to achieve high thermal efficiency and electrical energy. Theoretical analysis of the system performance has been performed. The advantages of the collector, which used air or water as a cooling fluid, have been discussed. 
Table 1 Specifications and efficiency values of previous studies of PV/T collectors

\begin{tabular}{|c|c|c|c|c|}
\hline Ref. & PV/T type & Application & Efficiency & Area, material \\
\hline$[10]$ & Flat Plate & Hot water supply & Electrical: $13.9 \%$ & $20.44 \mathrm{~m}^{2},-$ \\
\hline$[11]$ & Flat Plate & Hot water supply & $\begin{array}{l}\text { Thermal: } 44.5 \% \\
\text { Electrical: } 9 \%\end{array}$ & $5.2 \mathrm{~m}^{2}$, polycrystalline \\
\hline$[12]$ & Flat Plate & Hot water supply & $\begin{array}{l}\text { Electrical: } 13-13.8 \% \\
\text { Thermal: } 45-54.6 \% \\
\text { Overall: } 58-68.4 \%\end{array}$ & $5.1 \mathrm{~m}^{2}$, polycrystalline silicon \\
\hline$[13]$ & Flat Plate & Hot water supply & $\begin{array}{l}\text { Electrical: } 9.87 \% \\
\text { Thermal: } 40 \%\end{array}$ & $1.64 \mathrm{~m}^{2},-$ \\
\hline$[14]$ & Flat Plate & Solar cooling & $\begin{array}{l}\text { Electrical: } 10.6 \% \\
\text { Thermal: } 71 \%\end{array}$ & $8.76 \mathrm{~m}^{2},-$ \\
\hline$[15]$ & Flat Plate & Hot water supply & $\begin{array}{l}\text { Exergy: } 14.2 \% \\
\text { Electrical: } 13.4-13.5 \% \\
\text { Overall: } 70 \%\end{array}$ & $3.18 \mathrm{~m}^{2}$, polycrystalline \\
\hline$[16]$ & Non concentrate $\mathrm{PV} / \mathrm{T}$ & Solar cooling & $\begin{array}{l}\text { Thermal: } 62 \% \\
\text { Electrical: } 13.19 \%\end{array}$ & - \\
\hline$[17]$ & $\mathrm{CPV} / \mathrm{T}$ & Space heating + cooling & $\begin{array}{l}\text { Electrical: } 11 \% \\
\text { Thermal } 59 \%\end{array}$ & - \\
\hline$[18]$ & $\mathrm{CPV} / \mathrm{T}$ & Hot water supply & $\begin{array}{l}\text { Electrical: } 7.36-6.85 \% \\
\text { Thermal: } 22.1-7.33 \%\end{array}$ & - \\
\hline [19] & $\mathrm{CPV} / \mathrm{T}$ & Solar cooling & $\begin{array}{l}\text { Electrical: } 11 \% \\
\text { Thermal: } 58 \%\end{array}$ & $1.8 \mathrm{~m}^{2},-$ \\
\hline$[20]$ & $\mathrm{CPV} / \mathrm{T}$ & Solar cooling & $\begin{array}{l}\text { Thermal: } 44 \% \\
\text { Electrical: } 6 \%\end{array}$ & $1 \mathrm{~m}^{2}$, monocrystalline \\
\hline$[21]$ & $\begin{array}{c}\mathrm{BIPV} / \mathrm{T} \\
\text { (Building integrated) }\end{array}$ & - & $\begin{array}{l}\text { Thermal: } 48 \% \\
\text { Electrical: } 10.8 \%\end{array}$ & $1.65 \mathrm{~m}^{2}$, polycrystalline \\
\hline$[22]$ & $\mathrm{BIPV} / \mathrm{T}$ & Space heating + hot water supply & $\begin{array}{l}\text { Thermal: } 40 \% \\
\text { Electrical: } 8 \%\end{array}$ & $1.42 \mathrm{~m}^{2}$, monocrystalline \\
\hline$[23]$ & $\begin{array}{c}\text { BICPV } \\
\text { (Building integrated concentrating) }\end{array}$ & - & $\begin{array}{l}\text { Thermal: } 54 \% \\
\text { Electrical: } 13.9 \%\end{array}$ & - \\
\hline$[24,25]$ & $\mathrm{BIPV} / \mathrm{T}$ & - & $\begin{array}{l}\text { Thermal: } 48 \% \\
\text { Electrical: } 16.4 \%\end{array}$ & - \\
\hline
\end{tabular}

\section{ENERGY ANALYSIS}

The energy analysis is required to determine the performance of the designed novel modular $\mathrm{PV} / \mathrm{T}$ collector. The energy equations of $\mathrm{PV} / \mathrm{T}$ collector which is simultaneously produced both heat and electrical energy are given below [26]:

$\sum \dot{E}_{\text {in }}=\sum \dot{E}_{\text {out }}$

Electrical efficiency of a photovoltaic module is given as follows [27]:

$\eta_{\mathrm{el}}=\eta_{\mathrm{ref}}\left[1-\beta_{\mathrm{ref}}\left(T_{\mathrm{PV}}-T_{\text {ref }}\right)\right]$

Here, $\beta_{\text {ref }}=0.0045^{\circ} \mathrm{C}^{-1}$ is the temperature coefficient [28]. $T_{\mathrm{PV}}$ is the temperature of the PV cells and $T_{\text {ref }}$ is the reference temperature which is taken as $25^{\circ} \mathrm{C}$. $\eta_{\text {ref }}$ is the reference PV module efficiency (0.09). $T_{\mathrm{PV}}$ has been chosen as $44.70{ }^{\circ} \mathrm{C}$ according to the reference case [29].

$Q_{\mathrm{th}, \text { ins }}=\dot{m}_{\mathrm{a}} C_{\mathrm{p}, \mathrm{a}}\left(T_{\mathrm{a}, \mathrm{o}}-T_{\mathrm{a}, \mathrm{i}}\right)$

$Q_{\mathrm{th}, \mathrm{ins}}=\dot{m}_{\mathrm{w}} C_{\mathrm{p}, \mathrm{w}}\left(T_{\mathrm{w}, \mathrm{o}}-T_{\mathrm{w}, \mathrm{i}}\right)$

Here $\dot{m}_{\mathrm{a}}$ and $\dot{m}_{\mathrm{w}}$ are mass flow rates $(\mathrm{kg} / \mathrm{s})$ for air and water, respectively. $C_{\mathrm{p}, \mathrm{a}}$ is the spesific heat capacity of air and $C_{\mathrm{p}, \mathrm{w}}$ is the specific heat capacity of water $(\mathrm{kJ} / \mathrm{kgK}) . T_{\mathrm{a}, \mathrm{i}}$ and
$T_{\mathrm{w}, \mathrm{i}}$ are the inlet temperature of the air and water, respectively. Total instantaneous thermal efficiency of the solar collector for air and water working fluids can be calculated with Eq. (5) and Eq. (6), respectively.

$\sum \eta_{\mathrm{th}, \mathrm{ins}}=\frac{\dot{m}_{\mathrm{a}} C_{\mathrm{p}, \mathrm{a}}\left(T_{\mathrm{a}, \mathrm{o}}-T_{\mathrm{a}, \mathrm{i}}\right)}{I A_{\mathrm{c}}}$
$\sum \eta_{\mathrm{th}, \mathrm{ins}}=\frac{\dot{m}_{\mathrm{w}} C_{\mathrm{p}, \mathrm{w}}\left(T_{\mathrm{w}, \mathrm{o}}-T_{\mathrm{w}, \mathrm{i}}\right)}{I A_{\mathrm{c}}}$

Here $I$ is the solar radiation value $\left(\mathrm{W} / \mathrm{m}^{2}\right)$ and $A_{\mathrm{c}}$ is the collector area $\left(\mathrm{m}^{2}\right)$. Total thermal efficiency of the solar collector for air and water working fluids can be computed as follows [27]:

$$
\begin{aligned}
& \sum \eta_{\mathrm{th}}=\frac{\int\left[\dot{m}_{\mathrm{a}} C_{\mathrm{p}, \mathrm{a}}\left(T_{\mathrm{a}, \mathrm{o}}-T_{\mathrm{a}, \mathrm{i}}\right)\right] \mathrm{d} t}{A_{\mathrm{c}} \int I \mathrm{~d} t} \\
& \sum \eta_{\mathrm{th}}=\frac{\int\left[\dot{m}_{\mathrm{w}} C_{\mathrm{p}, \mathrm{w}}\left(T_{\mathrm{w}, \mathrm{o}}-T_{\mathrm{w}, \mathrm{i}}\right)\right] \mathrm{d} t}{A_{\mathrm{c}} \int I \mathrm{~d} t}
\end{aligned}
$$

Total PV/T efficiency can be calculated with Eq. (9) and Eq. (10) for air and water, respectively. 


$$
\begin{aligned}
& \sum \eta_{\mathrm{PV} / \mathrm{T}}=\frac{\int\left[\dot{m}_{\mathrm{a}} C_{\mathrm{p}, \mathrm{a}}\left(T_{\mathrm{a}, \mathrm{o}}-T_{\mathrm{a}, \mathrm{i}}\right)\right] \mathrm{d} t}{A_{\mathrm{c}} \int I \mathrm{~d} t}+\frac{\int P_{\mathrm{el}} \mathrm{d} t}{A_{\mathrm{c}} \int I \mathrm{~d} t} \\
& \sum \eta_{\mathrm{PV} / \mathrm{T}}=\frac{\int\left[\dot{m}_{\mathrm{w}} C_{\mathrm{p}, \mathrm{w}}\left(T_{\mathrm{w}, \mathrm{o}}-T_{\mathrm{w}, \mathrm{i}}\right)\right] \mathrm{d} t}{A_{\mathrm{c}} \int I \mathrm{~d} t}+\frac{\int P_{\mathrm{el}} \mathrm{d} t}{A_{\mathrm{c}} \int I \mathrm{~d} t}
\end{aligned}
$$

$P_{\text {el }}$ is electrical power (W). In this study, electrical efficiency was calculated as 0.082 at the constant solar radiation value of $700 \mathrm{~W} / \mathrm{m}^{2}$.

\section{SYSTEM DESIGN AND MODELS}

There are a lot of works about cooling of PV unit. Generally, air or water cooled PV has been used. When the previous studies are examined, the electrical efficiency in the systems using crystalline solar panels is higher than the systems using thin film panels, while the thermal efficiency is lower. This difference is due to the fact that the crystalline solar panel efficiency is higher than the thin film solar panel efficiency, whereas the thermal efficiency is high in the PV/T panel used in the thin film panel because the heat transfer coefficient value of the thin film solar panels is higher than of the crystalline solar panels. As the glass is used as a cover in the collector, the electrical efficiency decreases while the thermal efficiency increases. The main reason for this situation is that the glass material used on the collector surface does not allow much heat transfer and the increase in the temperature within the system increases every $1{ }^{\circ} \mathrm{C}$ above $25{ }^{\circ} \mathrm{C}$ by $0.4 \%$ and $0.5 \%$ in the efficiency of PV cells. Thermal efficiency of the water-cooled PV/T is higher than air-cooled PV/T collectors, while the electrical efficiency is the same. The reason why water-cooled $\mathrm{PV} / \mathrm{T}$ collector thermal efficiency is high is due to the fact that water is a better heat conductor than air.

Within the framework of the evaluations carried out, the highest efficiency of total $\mathrm{PV} / \mathrm{T}$ collector is the $\mathrm{PV} /$ water+glass characteristics and the lowest efficient $\mathrm{PV} / \mathrm{T}$ collectors are the polycrystalline PV/air characteristic.

While designing the system, it is aimed to produce thermal energy besides electricity production. As it is known, the hottest area of contact with the fluid in the system is the area under the PV panel. When we approach the whole system step by step, it can be seen that there are several options to increase the heat transfer. Since we cannot make changes in the bottom surface of the PV panel, the ratio of the area contacting / not touching the bottom surface, the total heat transfer area, the thermal conductivity coefficient of the tubes or fins, the velocities of the primary and secondary fluid and turbulence levels.

There are copper pipes in contact with the panel along the PV. The pipes in which the primary fluid circulates are in contact with PV panel. Also, there are copper fins under the PV panel to heat the air. Depending on demand, air or water can be used as working fluid. Also, an electrical insulation material can be applied between the PV panel and the copper pipes for electrical insulation and to provide high thermal conductivity. Schematic view of modular PV/T collector is given in Fig. 1. PV/T collector can operate in two modes. Air and water are the working fluids for Mode 1 and Mode 2, respectively. Working fluids can be selected and the PV/T collector can produce water or air depending on the demand.

Designed PV module can work efficiently using a proportional integral derivative (PID) controller. When the PV surface temperature, which is measured by the thermocouple, reaches the high value, in other words, PV surface temperature increases, fan or pump adjusts the flow rate by means of the inverter according to the measured temperature value. As the PV panel surface temperature increases, the flow rate of coolant fluid increases proportionally. In theoretical calculations, main water system utilization has been assumed. It has been assumed that there was no recirculation.

In this design, the electrical efficiency characterization is important due to the temperature of the PV module. With this design, the flow rate of coolant in which the PV panel will operate efficiently can be managed.

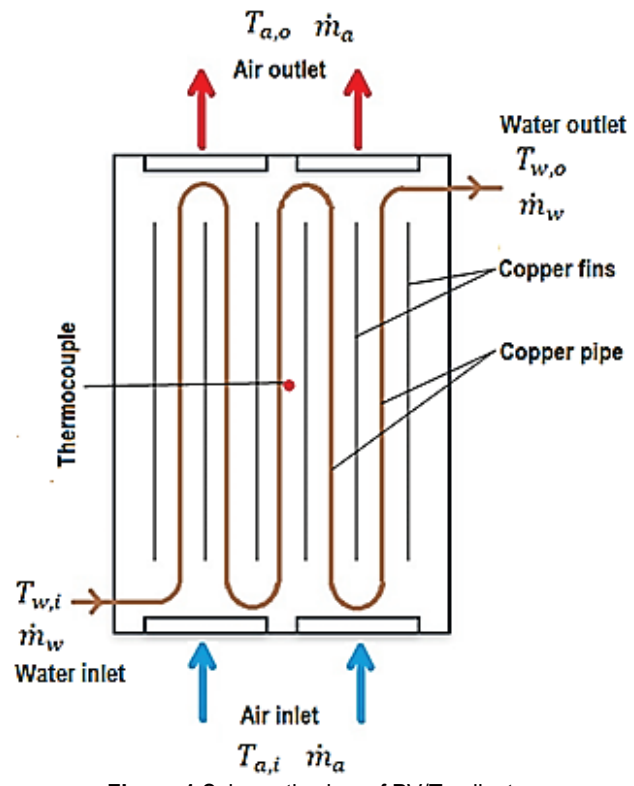

Figure 1 Schematic view of PV/T collector

The advantages of design of the novel photovoltaicthermal (PV/T) collector system:

- the increase of PV panel efficiency according to the conventional one,

- obtaining both electrical and heat energy from solar energy,

- increasing efficiency by using air-water at variable flow rate according to the radiation intensity from the sun,

- air or water heating on demand with a single system.

\section{RESULTS AND DISCUSSION}

$\mathrm{PV} / \mathrm{T}$ efficiency values depending on mass flow rate of Mode 1 are given in Fig. 2. As can be seen in Fig. 2 and 3, the increase in the mass flow rate value increases the PV/T efficiency. 
Theoretical calculations for airflow mode (Mode 1) $\mathrm{PV} / \mathrm{T}$ have been done at $0.0067 \mathrm{~kg} / \mathrm{s}, 0.0072 \mathrm{~kg} / \mathrm{s}$ and 0.0077 $\mathrm{kg} / \mathrm{s}$ mass flow rates. The total efficiency for this mode were calculated as $43.2 \%, 46.2 \%$ and $48.7 \%$, respectively.

$\mathrm{PV} / \mathrm{T}$ efficiency values depending on the mass flow rate of Mode 2 are given in Fig. 3. PV/T efficiency of water flow mode also increased with the increment of the mass flow rate of water as in air flow mode.

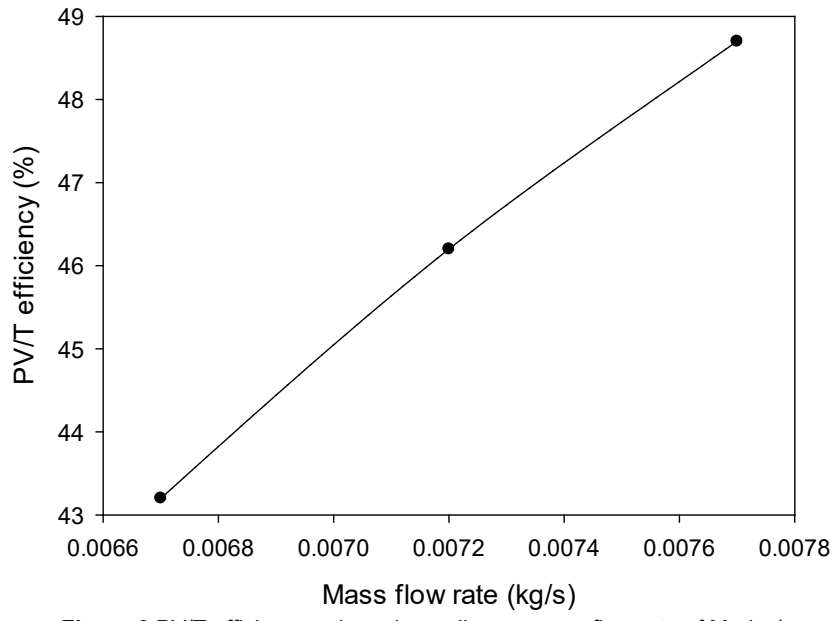

Figure $2 \mathrm{PV} / \mathrm{T}$ efficiency values depending on mass flow rate of Mode 1

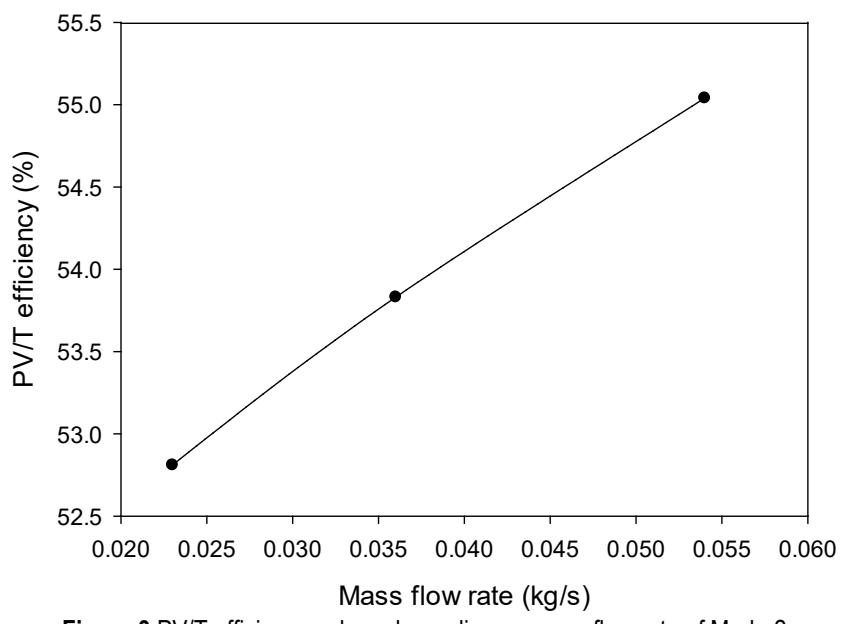

Figure $3 \mathrm{PV} / \mathrm{T}$ efficiency values depending on mass flow rate of Mode 2

\section{CONCLUSION}

In the last decade, high effective PV/T systems have become much popular issue within the solar application. In this study, a new type of $\mathrm{PV} / \mathrm{T}$ system was designed to increase the efficiency of a conventional PV panel. With this novel design, air or water can be used as a cooling fluid. In this way, the efficiency of the PV panel can be increased and the desired hot fluid for the food and agricultural applications can be obtained. Moreover, when solar irradiation is abundant, a large part of the energy load can be met from a renewable source. While the efficiency of a conventional PV panel is average $15-20 \%$, the total efficiency of air flow mode (Mode 1) was calculated as $43.2 \%, 46,2 \%$ and $48.7 \%$ at $0.0067 \mathrm{~kg} / \mathrm{s}, 0.0072 \mathrm{~kg} / \mathrm{s}$ and $0.0077 \mathrm{~kg} / \mathrm{s}$ mass flow rates, respectively. For water flow mode (Mode 2), these values were computed as $52.81 \%, 53.83 \%$ and $55.04 \%$ at 0.023 $\mathrm{kg} / \mathrm{s}, 0.036 \mathrm{~kg} / \mathrm{s}$ and $0.054 \mathrm{~kg} / \mathrm{s}$ mass flow rates, respectively. With this design, the electrical and heat energy are acquired in the most efficient way. In addition, a more stable PV/T system with the heat energy obtained in the same area can be used in many production processes. Especially, this PV/T system design can be used efficiently in drying of food, preheating of food and agricultural products processes as well as space heating and domestic hot water production.

\section{REFERENCES}

[1] Khanlari, A., Güler, H. Ö., Tuncer, A.D., Şirin, C., Bilge Y. C., Y1lmaz, Y., \& Güngör, A. (2020). Experimental and numerical study of the effect of integrating plus-shaped perforated baffles to solar air collector in drying application. Renewable Energy, 145, 1677-1692. https://doi.org/10.1016/j.renene.2019.07.076

[2] Khanlari, A., Sözen, A., Şirin, C., Tuncer, A. D. \& Gungor, A. (2020). Performance enhancement of a greenhouse dryer: Analysis of a cost-effective alternative solar air heater. Journal of Cleaner Production, 251, 119672. https://doi.org/10.1016/j.jclepro.2019.119672

[3] Hasan, M. A. \& Sumathy, K. (2010). Photovoltaic thermal module concepts and their performance analysis: A review. Renewable and Sustainable Energy Reviews, 14, 1845-1859. https://doi.org/10.1016/j.rser.2010.03.011

[4] Kalogirou, S. A. \& Tripanagnostopoulos, Y. (2006). Hybrid $\mathrm{PV} / \mathrm{T}$ solar systems for domestic hot water and electricity production. Energy Conversion and Management, 47, 33683382. https://doi.org/10.1016/j.enconman.2006.01.012

[5] Ceylan, İ., Gürel, A.E., Demircan, H., \& Aksu B. (2014). Cooling of a photovoltaic module with temperature controlled solar collector. Energy and Buildings, 72, 96-101. https://doi.org/10.1016/j.enbuild.2013.12.058

[6] Ceylan, İ. \& Gürel, A. E. (2015). Exergetic Analysis of a New Design Photovoltaic and Thermal (PV/T) System. American Institute of Chemical Engineers Environ Prog, 34, 1249-1253. https://doi.org/10.1002/ep.12108

[7] Zondag, H. A. (2008). Flat-plate PV-Thermal collectors and systems: A review. Renewable and Sustainable Energy Reviews, 12, 891-959. https://doi.org/10.1016/j.rser.2005.12.012

[8] Aktaş, M., Sözen, A., Tuncer, A. D., Arslan, E., Koşan, M., \& Çürük, O. (2019). Energy-Exergy Analysis of a Novel MultiPass Solar Air Collector with Perforated Fins. International Journal of Renewable Energy Development, 8(1), 47-55. https://doi.org/10.14710/ijred.8.1.47-55

[9] Şevik, S., Aktaş, M., Dolgun, E. C., Arslan, E., \& Tuncer, A. D. (2019). Performance analysis of solar and solar-infrared dryer of mint and apple slices using energy-exergy methodology. Solar Energy, 180, 537-549. https://doi.org/10.1016/j.solener.2019.01.049

[10] Bianchini, A., Guzzini, A., Pellegrini, M., \& Saccani, C. (2017). Photovoltaic/thermal (PV/T) solar system: Experimental measurements, performance analysis and economic assessment. Renewable Energy, 111, 543-555. https://doi.org/10.1016/j.renene.2017.04.051

[11] Huang, B. J., Lin, T. H., Hung, W. C., \& Sun, F. S. (2001). Performance Evaluation of Solar Photovoltaic/Thermal Systems. Solar Energy, 70, 443-448. https://doi.org/10.1016/S0038-092X(00)00153-5

[12] Fudholi, A., Sopian, K., Yazdi, M. H., Ruslan, M. H., Ibrahim, A., \& Kazem, H. A. (2014). Performance analysis of 
photovoltaic thermal (PVT) water collectors. Energy Conversion and Management, 78, 641-651. https://doi.org/10.1016/j.enconman.2013.11.017

[13] He, W., Chow, T. T., Ji, J., Lu, J., Pei, G., \& Chan, L. (2006). Hybrid photovoltaic and thermal solar-collector designed for natural circulation of water. Applied Energy, 83, 199-210. https://doi.org/10.1016/j.apenergy.2005.02.007

[14] Nasrin, R., Hasanuzzaman, M., \& Rahim, N. A., (2017). Effect of high irradiation and cooling on power, energy and performance of a PVT system. Renewable Energy, 116, 552569. https://doi.org/10.1016/j.renene.2017.10.004

[15] Evola, G. \& Marletta, L. (2014). Exergy and thermoeconomic optimization of a water-cooled glazed hybrid photovoltaic/ thermal (PVT) collector. Solar Energy, 107, 12-25. https://doi.org/10.1016/j.solener.2014.05.041

[16] Rosa-Clot, M., Rosa-Clot, P., Tina, G. M., \& Ventura, C. (2016). Experimental photovoltaic-thermal Power Plants based on TESPI panel. Solar Energy, 133, 305-314. https://doi.org/10.1016/j.solener.2016.03.024

[17] Xu, Z. \& Kleinstreuer, C., (2014). Concentration photovoltaicthermal energy co-generation system using nanofluids for cooling and heating. Energy Conversion and Management, 87, 504-512. https://doi.org/10.1016/j.enconman.2014.07.047

[18] Tiwari, G. N. \& Gaur, A. (2014). Photovoltaic thermal (PVT) systems and its applications. $2^{\text {nd }}$ International Conference on Green Energy and Technology, Dhaka, Bangladesh, 132-138. https://doi.org/10.1109//CGET.2014.6966678

[19] Coventry, J. S. (2005). Performance of a concentrating photovoltaic/thermal solar collector. Solar Energy, 78, 211222. https://doi.org/10.1016/j.solener.2004.03.014

[20] Karathanassis, I. K., Papanicolaou, E., Belessiotis, V., \& Bergeles, G. C. (2017). Design and experimental evaluation of a parabolic-trough concentrating photovoltaic/thermal (CPVT) system with high efficiency cooling. Renewable Energy, 101, 467-483. https://doi.org/10.1016/j.renene.2016.09.013

[21] Ibrahim, A., Fudholi, A., Sopian, K., Othman, M. Y., \& Ruslan, M. H. (2014). Efficiencies and improvement potential of building integrated photovoltaic thermal (BIPVT) system. Energy Conversion and Management, 77, 527-534. https://doi.org/10.1016/j.enconman.2013.10.033

[22] Hazami, M., Mehdaoui, F., Naili, N., Noro, M., \& Lazzarin, R., G., A. (2017). Energetic, exergetic and economic analysis of an innovative SolarCombiSystem (SCS) producing thermal and electric energies: Application in residential and tertiary households. Energy Conversion and Management, 140, 36-50. https://doi.org/10.1016/j.enconman.2017.02.040

[23] Connelly, K., Wu, Y., Chen, J., \& Lei, Y. (2016). Design and development of a reflective membrane for a novel Building Integrated Concentrating Photovoltaic (BICPV) 'Smart Window' system. Applied Energy, 182, 331-339. https://doi.org/10.1016/j.apenergy.2016.07.125

[24] Farshchimonfared, M., Bilbao, J. I., \&. Sproul, A. B. (2016). Full optimisation and sensitivity analysis of a photovoltaicthermal $(\mathrm{PV} / \mathrm{T})$ air system linked to a typical residential building. Solar Energy, 136, 15-22. https://doi.org/10.1016/j.solener.2016.06.048

[25] Delisle, V. \& Kummert, M., (2016). Cost-benefit analysis of integrating BIPV-T air systems into energy-efficient homes. Solar Energy, 136, 385-400. https://doi.org/10.1016/j.solener.2016.07.005

[26] Sardarabadi, M., Hosseinzadeh, M., Kazemian, A., \& Fard M. P. (2017). Experimental investigation of the effects of using metal-oxides/water nanofluids on a photovoltaic thermal system (PVT) from energy and exergy viewpoints. Energy, 138, 682-695. https://doi.org/10.1016/j.energy.2017.07.046
[27] Tiwari, A. \& Sodha, M. S. (2006). Performance evaluation of solar PV/T system: An experimental validation. Solar Energy, 80, 751-759. https://doi.org/10.1016/j.solener.2005.07.006

[28] Zondag, H. A., de Vries, D. W., van Helden, W. G. J., van Zolengen, R. J. C., \& van Steenhoven, A. A. (2002). The thermal and electrical yield of a PV-thermal collector. Solar Energy, 72, 113-128. https://doi.org/10.1016/S0038-092X(01)00094-9

[29] Jarimi, H., \& Abu Bakar, M. N., Othman, M., \& Din, M. H. (2016). Bi-fluid photovoltaic/thermal (PV/T) solar collector: Experimental validation of a 2-D theoretical model. Renewable Energy, 85, 1052-1067. https://doi.org/10.1016/j.renene.2015.07.014

\section{Authors' contacts:}

Erhan Arslan, MSc

Institute of Natural and Applied Science,

Gazi University,

Teknikokullar, Ankara, Turkey

Erhana1985@gmail.com

Azim Doğuş Tuncer*, MSc, Research Assistant

Energy Systems Engineering,

Faculty of Engineering-Architecture,

Burdur Mehmet Akif Ersoy University,

İstiklal Campus, Burdur, Turkey

azimdtuncer@gmail.com

Meltem Koşan, MSc, Research Assistant

Energy Systems Engineering,

Technology Faculty, Gazi University,

Teknikokullar, Ankara, Turkey

polat.meltem@gazi.edu.tr

Ekin Can Dolgun

Institute of Natural and Applied Science,

Gazi University,

Teknikokullar, Ankara, Turkey

ekincandolgun@gmail.com

Mustafa Aktaş, PhD, Professor

Energy Systems Engineering,

Technology Faculty, Gazi University,

Teknikokullar, Ankara, Turkey

mustafaaktas@gazi.edu.tr 